\title{
Pemberian Motivasi Melalui Cerita Dan Games Untuk Menumbuhkan Minat Belajar Anak Usia SD Dan SMP
}

\author{
Etty Ratnawati ${ }^{1 *}$ Aas Asniawati ${ }^{2}$ \\ IAIN Syekh Nurjati Cirebon \\ 1e-mail: ettyratnawati@syekhnurjati.ac.id \\ 2e-mail: asniawatiaas1@gmail.com \\ *Corresponding Author
}

\begin{abstract}
ABSTRAK
Kreatifitas guru dalam mengajar salah satunya berupa metode mengajar dan penggunaan media pembelajaran. Pada masa sekarang ini dalam sebuah sistem pendidikan modern, fungsi guru sebagai penyampai pesan pendidikan tampaknya memang sangat perlu dibantu dengan media pembelajaran, seperti cerita dan games agar proses pembelajaran dapat berjalan secara efektif dan juga dapt memotivasi minat anak untuk belajar. Penelitian ini bertujuan untuk mendeskripsikan bagaimana penerapan pemberian motivasi melalui cerita dan games untuk meningkatkan minat belajar anak usia SD dan SMP. Metode penelitian yang digunakan adalah menggunakan penelitian deskriptif dengan pendekatan kualitatif, instrument utama adalah peneliti itu sendiri. Dalam penelitian ini teknik pengumpulan data yang digunakan yaitu wawancara, observasi, dan dokumentasi. Penelitian dilaksanakan di Desa Nagarajati Kecamatan Panawangan Kabupaten Ciamis pada bulan juli saat pelaksanaan KKN-DR 2020. Pemberian motivasi melalui cerita dan games dilakukan setiap kegiatan bimbingan belajar untuk meningkatkan minat belajar anak.
\end{abstract}

Kata Kunci: Motivasi, Cerita, Games

\begin{abstract}
One of the teachers' creativity in teaching is the teaching method and the use of learning media. At present, in a modern education system, the teacher's function as a messenger of education seems to really need to be assisted with learning media, such as stories and games so that the learning process can run effectively and can also motivate children's interest in learning. This study aims to describe how the application of motivation through stories and games to increase learning interest in elementary and junior high school age children. The research method used is descriptive research with a qualitative approach, the main instrument is the researcher himself. In this study, the data collection techniques used were interviews, observation, and documentation. The research was carried out in Nagarajati Village, Panawangan District, Ciamis Regency in July during the implementation of the 2020 KKNDR. Motivation through stories and games is carried out in every tutoring activity to increase children's learning interest.
\end{abstract}

Keywords: Motivation, Stories, Games 


\section{PENDAHULUAN}

Pendidikan merupakan program yang terencana untuk meningkatkan dan mewujudkan proses pembelajaran yang menyenangkan sehingga peserta didik mampu mengembangkan diri dalam belajarnya. Sebagaimana pengertian pendidikan yang tertuang dalam Undang-Undang No. 20 Tahun 2003, bahwa pendidikan adalah usaha sadar dan terencana untuk mewujudkan suasana belajar dan proses pembelajaran agar peserta didik secara aktif mengembangkan potensi dirinya.

Belajar termasuk salah satu hal yang penting, apalagi bagi anak-anak remaja. Namun banyak masalah yang muncul pada mereka dimana anak-anak remaja sekarang cenderung malas untuk belajar, dan memilih melakukan aktivitas lain yang menurut mereka menarik. Apalagi di masa covid sekarang ini. Alasan mereka malas belajar bisa jadi karena lelah, tidak ada semangat untuk belajar, bosan/jenuh dengan sistem pembelajarannya sekarang ini, atau juga susah untuk berkonsentrasi ketika disuruh belajar. Usia remaja memang rentan terhadap hal-hal baru atau lingkungan dan pergaulan baru. Inilah salah faktor yang menjadi penyebab remaja banyak yang malas untuk belajar. Untuk itu perlu adanya motivasi untuk menumbuhkan minat belajar pada mereka.

Dalam proses pembelajaran, minat merupakan penggerak awal bagi seorang siswa dalam belajar yang dapat digunakan untuk mencapai tujuan yang diinginkan, yakni tujuan pembelajaran. Seseorang yang memiliki minat belajar dalam dirinya maka dia akan mencapai keinginan atau citacitanya. Minat belajar seorang anak sangat dibutuhkan dalam pembelajaran agar anak tersebut memiliki ketertarikan terhadap materi yang diajarkan. Disamping itu, seorang anak juga membutuhkan dorongan untuk mencapai keinginan atau cita-citanya.

Minat merupakan aspek terpenting guna memotivasi siswa supaya mencapai perhatian dalam belajar dan berprestasi. Untuk itu perlu dipilihnya objek serta kegiatan yang lebih menguntungkan, menyenangkan, menggembirakan dan mendatangkan kepuasan tersendiri dalam diri seseorang. Oleh karena itu, agar siswa mampu memperoleh hasil yang baik dalam belajar maka seorang siswa harus mempunyai minat terhadap pelajaran sehingga akan membantu untuk terus belajar. Untuk tercapainya kegiatan tersebut tidaklah mudah perlu adanya sebuah proses, perlu adanya bimbingan serta pengarahan atau juga motivasi yang baik dari guru atau juga peran orang tua yang menjadi pemicu utama keberhasilan seorang anak agar terdorong ke arah yang baik.

Adapun cara seorang guru menumbuhkan minat belajar pada siswa diantaranya dengan memberikan motivasi yang baik pada diri anak didik, sehingga dia rela belajar tanpa adanya keterpaksaan. Selain itu juga dengan memberikan berbagai macam bentuk dan teknik dalam mengajar individual anak didik agar anak dengan mudah memahaminya, misalnya dalam bentuk 
games atau permainan dan juga cerita.

Desa Nagarajati merupakan salah satu desa di Kecamatan Panawangan, Kabupaten Ciamis. Ditinjau dari segi pendidikan, di Desa Nagarajati masih sedikit lulusan sarjana, hanya ada beberapa orang yang dapat meneruskan ke perguruan tinggi. Minat belajar anak di era new normal terlihat masih rendah, banyak anak yang tidak menggunakan waktu untuk hal bermanfaat serta kurang motivasi dari orang tua mengenai pentingnya pendidikan. Hal ini harus diperhatikan, karena menyangkut masa depan anak-anak desa khususnya anak usia SD dan SMP.

Perlu bagi orang dewasa dan orang sekitar untuk meningkatkan minat belajar anak. Banyak hal yang mempengaruhi minat belajar anak, salah satunya yaitu dengan pemberian motivasi yang dilakukan oleh orang-orang sekitar anak- anak. Motivasi adalah keadaan internal yang membangkitkan seseorang untuk melakukan tindakan, terdorong untuk mencapai tujuan tertentu atau membuat individu tertarik untuk melakukan aktivitas tertentu. Motivasi belajar yang tinggi akan memunculkan minat belajar yang tinggi.

Motivasi belajar siswa merupakan salah satu faktor pendorong suksesnya atau terlaksananya pembelajaran dengan baik, tanpa adanya motivasi belajar yang tinggi, proses pembelajaran akan menjadi terhambat karena anak tidak akan serius atau sungguh-sungguh dalam belajar sehingga hal ini akan mempengaruhi minat belajar anak dalam belajar. Pemberian motivasi belajar untuk meningkatkan minat belajar anak dapat dilakukan dengan metode pembelajaran yang dapat memunculkan minat belajar anak (Eliska, 2018). Oleh karena itu pada kegiatan pengabdian yang dilakukan peneliti bulan Juli 2020 lebih menekankan kepada pemberian motivasi dengan melalui upaya-upaya tertentu. Salah satu upaya untuk meningkatkan belajar yang telah dilakukan pada saat pengabdian yaitu pemberian motivasi melalui metode pembelajaran yang dapat meningkatkan minat belajar anak yaitu pemberian motivasi melalui cerita dan games.

\section{BAHAN DAN METODE}

Penelitian dilakukan pada saat KKN-DR 2020 di Desa Nagarajati, Kecamatan Panawangan, Kabupaten Ciamis. Ruang lingkup penelitian termasuk dalam bidang pendidikan pada anak usia SD dan SMP. Penelitian ini adalah penelitian deskriptif dengan pendekatan kualitatif. Data dalam penelitian ini berupa data kualitatif, yaitu dengan menggunakan kata-kata atau deskripsi mengenai fakta atau fenomena yang diamati. Pengumpulan data dalam penelitian kualitatif dikumpulkan dalam kondisi yang asli atau alamiah (natural setting). Dalam penelitian ini penulis melakukan pengumpulan data melalui dokumentasi, observasi, dan wawancara. Dokumentasi dilakukan dengan 
mendata anak-anak yang hadir dalam kegiatan pemberian motivasi. Observasi dilakukan pada saat kegiatan pemberian motivasi berlangsung. Wawancara dilakukan pada tanggal 29 Juli bersamaan dengan evaluasi belajar.

Dalam penelitian kualitatif, yang menjadi instrument utama atau alat penelitian adalah peneliti itu sendiri. Populasi dalam penelitian ini adalah seluruh anak usia SD dan SMP yang ada di Desa Nagarajati. Sampel dalam penelitian ini adalah anak usia SD dan SMP yang telah mengikuti bimbingan belajar selama KKN-DR yaitu sebanyak 31 anak. Variabel bebas dalam penelitian ini yaitu pemberian motivasi melalui cerita dan games. Variabel terikat dalam penelitian ini adalah minat belajar anak.

\section{HASIL DAN PEMBAHASAN}

Motivasi dapat diartikan sebagai suatu usaha yang ada dalam diri seseorang (individu) baik berupa sikap, tindakan dan dorongan untuk bertindak dalam mengarahkan serta menggerakan individu pada suatu tingkah laku sehingga tujuan yang dikehendaki dapat tercapai (Setianingsih, 2018). Sumber dorongan tersebut dapat berasal dari dalam diri pribadi seseorang itu sendiri (motivasi intrinsik) maupun dari luar pribadi (motivasi ekstrinsik) (Bakhri, dkk, 2020). Memberikan motivasi kepada anak didik berarti menggerakan anak didik untuk melakukan sesuatu, termasuk menggerakan anak didik untuk meningkatkan minat belajar. Pemberian motivasi ini sudah seharusnya dilakukan dalam kegiatan proses belajar, agar tujuan belajar berhasil serta meningkatkan minat belajar anak

Minat merupakan moment-moment dari kecendrungan jiwa yang terarah secara intensif kepada suatu objek yang dianggap paling efektif (perasaan, emosional) yang didalamnya terdapat elemen-elemen efektif (emosi) yang kuat (Zarkasi dan Lutfianto, 2017). Minat dan belajar merupakan suatu kesatuan yang tidak dapat terpisahkan karena keduanya saling berhubungan, dan juga merupakan salah satu poin penting yang harus dimiliki oleh anak didik dalam belajar guna memotivasi anak supaya mencapai perhatian, belajar, dan berprestasi. Minat adalah dorongan dalam diri seseorang yang menimbulkan ketertarikan secara efektif pada hal lain.

Banyak cara yang bisa dilakukan untuk meningkatkan minat belajar anak, misalnya: memberikan motivasi yang baik pada diri anak didik sehingga dia rela belajar tanpa adanya keterpaksaan, memberikan kesempatan pada anak didik untuk belajar dengan lingkungan belajar yang kondusif dan kreatif, dan menggunakan berbagai macam bentuk dan teknik dalam mengajar individual anak didik agar anak dengan mudah memahaminya, misalnya dengan bercerita dan bermain atau melalui permainan (games). 
Ada anggapan bahwa bermain dan belajar adalah sesuatu yang bertolak belakang. Menurut anak, belajar itu menjemukan sedangkan bermain itu menyenangkan. Sedangkan para orang tua beranggapan, banyak bermain akan mengurangi waktu belajar. Padahal banyak aspek yang terkandung dalam bermain apalagi bermain yang memiliki unsur pendidikan. Dalam bermain terkandung aspek kegembiraan, kenikmatan yang intensif, kelegaan, bebas dari kedukaan dan ketegangan.

Melalui permainan kita bisa mengekspresikan diri, melatih pribadi untuk siap melewati persaingan, siap menerima kemenangan atau kekalahan, dan juga aktualisasi diri. Jadi, melalui bermain seseorang mendapat banyak ilmu pengetahuan, belajar banyak tentang kehidupan baik itu tentang kemandirian, keberanian, sosialisasi, dan kepemimpinan (Ratnaningsih, 2014:6). Permainan juga dapat membuat suasana lingkungan belajar menjadi hidup, menyenangkan, segar, bahagia, santai namun tetap dalam kondisi atau suasana belajar yang kondusif. Media permainan dapat digunakan sebagai salah satu upaya untuk meningkatkan motivasi siswa dalam belajar.

Dengan penelitian yang telah dilakukan pada program bimbingan belajar pada saat KKN-DR 2020 di Desa Nagarajati, hasil dari penelitian menunjukkan bahwa penerapan pemberian motivasi melalui cerita dan games dilakukan beberapa kali pada setiap proses pembelajaran bimbingan belajar pada saat KKNDR. Pada saat KKN-DR 2020 sebenarnya ada beberapa upaya untuk meningkatkan minat belajar yang telah dilaksanakan, namun upaya yang lebih sering digunakan untuk meningkatkan minat belajar anak usia SD dan SMP yaitu pemberian motivasi melalui cerita dan melalui games. Adapun proses kegiatan belajar antara SMP dan SD berbeda jadwal. Pembelajaran dilakukan sesuai kategori kelas dan dilakukan secara tatap muka dengan metode yang diharapkan dapat meningkatkan minat belajar anak.

Pemberian motivasi melalui cerita dilakukan dengan memberikan kisah/cerita kepada anak, istilah lain dikenal dengan bercerita. Bercerita berarti menyampaikan atau membacakan cerita kepada pendengar (Majid, 2001). Pemberian motivasi melalui cerita dijadikan sebagai media untuk membentuk kepribadian dan moralitas anak (Mulatsih dkk., 2018). Berdasarkan beberapa pendapat tersebut, pemberian motivasi melalui cerita dapat didefinisikan sebagai kegiatan menyampaikan cerita kepada pendengar (anak) untuk membentuk kepribadian anak salah satunya membentuk motivasi diri anak dalam belajar agar minat belajar meningkat.

Menurut Abdul Aziz Abdul Majid (2002), bahwa dalam cerita terdapat ide, tujuan, imajinasi, bahasa, dan gaya bahasa, dimana unsur-unsur tersebut berpengaruh dalam pembentukan pribadi anak, sehingga penetapan pelajaran bercerita pada masa awal sekolah dasar adalah bagian terpenting 
dari pendidikan. Begitu pula yang diungkapkan Kieran (2009), bahwa cerita membentuk pemahaman emosional kita terhadap isi dunia nyata dan juga materi fiksional. Pembentukan cerita dunia nyata inilah yang menjanjikan nilai paling besar dari pengajaran.

Pelaksanaan pemberian motivasi untuk anak usia SMP melalui cerita motivasi suatu tokoh atau cerita inspiratif lainnya dalam proses bimbingan belajar. Kegiatan belajar SMP diawali dengan literasi qurani, kemudian belajar materi pelajaran matematika, istirahat 5 menit, sesi pemberian motivasi melalui cerita, tanya jawab, berdoa sebelum pulang. Kegiatan pemberian motivasi dilakukan selama 5-10 menit, kemudian penulis membuka sesi tanya jawab mengenai cerita yang disampaikan. Respon anak-anak antusias bertanya mengenai apa yang mereka ingin tahu.

Metode bercerita merupakan metode yang dapat meningkatkan kemampuan berbahasa anak karena dengan bercerita anak dapat merespon dengan berbagai cara sesuai dengan yang ada difikiran anak tersebut. Melalui bercerita juga dapat merangsang minat baca dan minat tulis anak. Menurut MC. Donald (2005), motivasi anak dapat dirangsang melalui metode bercerita. Metode ini dapat merangsang watak dan karakter anak menjadi lebih baik, karena metode ini sangat disenangi anak sehingga motivasi anak dapat berkembang tanpa harus dipaksa. Dan kemampuan berbahasanya berkembang sesuai dengan tahap-tahap perkembangan anak.

Pelaksanaan pemberian motivasi pada saat KKN-DR melalui cerita untuk anak usia SD dilakukan dengan bercerita asyik inspiratif mengenai lalat, semut dan laba-laba penolong nyamuk. Anak-anak diberi kesempatan untuk maju ke depan menceritakan kembali apa yang telah kami sampaikan. Anak-anak berani maju dan menjawab pertanyaan apa yang kami berikan. Selain itu juga memberikan sebuah kisah inspiratif yang dapat membuat anak semangat belajar, contohnya dengan mengisahkan orang-orang yang sukses dengan kerja kerasnya. Kegiatan bercerita asyik inspiratif ini dilakukan setiap seminggu sekali untuk anak usia SD. Kegiatan bercerita asyik inspiratif dilakukan sebagai upaya untuk meningkatkan minat belajar anak.

Adapun pemberian motivasi melalui games dilakukan sebagai upaya untuk meningkatkan minat belajar anak usia SD dan SMP di Desa Nagarajati. Games berasal dari Bahasa Inggris yang berarti "permainan". Games yang diberikan kepada anak usia SD dan SMP pada bimbingan belajar saat KKN-DR yaitu games yang memotivasi dan yang memberi penguatan bagi anak-anak dalam belajar. Games atau permainan merupakan salah satu sarana yang bisa dijadikan sebagai jalan untuk melakukan transportasi ilmu kepada anak-anak (Nisak, 2014). Games merupakan salah satu sarana untuk meningkatkan perkembangan otak dan saraf motorik anak dengan cara yang santai dan menyenangkan (Eliska, 2018). Berdasarkan beberapa pendapat yang telah dikemukan maka dapat 
disimpulkan, bahwa games atau permainan adalah kegiatan yang menyenangkan guna meningkatkan perkembangan otak dan saraf motorik guna meningkatkan motivasi dan minat belajar.

Pemberian motivasi melalui games diberikan sebagai selingan dalam belajar. Adapun urutan kegiatan untuk melakukan games pada bimbingan belajar yaitu literasi qurani, belajar, istitrahat 510 menit, game, berdoa sebelum pulang. Dengan games anak-anak ceria dan gembira. Adapun games yang pernah diuji cobakan pada anak usia SD dan SMP yaitu duck game, tebak kata, ikuti apa yang saya lakukan jangan ikuti apa yang saya katakan, mengurutkan angka, bermain sambil belajar melalui media belajar ular tangga, dll. Games dilakukan sebagai upaya untuk meningkatkan minat belajar anak agar anak tidak bosan dalam belajar.

Salah satu games yang penulis gunakan dalam meningkatkan minat belajar anak adalah games dalam bentuk ular tangga. Media pembelajaran dalam bentuk ular tangga merupakan salah satu contoh media yang penulis buat sendiri. Manfaat media permainan ular tangga menurut Ratnaningsih (2014), yaitu bisa memberikan ilmu pengetahuan kepada anak melalui proses pembelajaran bermain sambil belajar, dan juga dapat merangsang pengembangan daya pikir, daya cipta, dan bahasa agar mampu menumbuhkan sikap, mental, serta akhlak yang baik.

Langkah-langkah yang penulis lakukan dalam pembuatan media pembelajaran ular tangga adalah sebagai berikut:

1. Siapkan bahan yang diperlukan, yaitu gunting, lem kertas, kertas origami ukuran $12 X 12 \mathrm{~cm}$, pulpen, kalender bekas, kotak kecil bekas, dan spidol whiteboard.

2. Menyiapkan 10 kertas origami ukuran $12 \times 12 \mathrm{~cm}$, gunting, kertas karton, lem kertas dan pulpen. Kemudian setiap satu buah kertas origami dipotong menjadi 3 bagian, lalu setiap kertas origami yang sudah dipotong ditekuk ditempelkan dengan lem kertas di kalender bekas. Kemudian buat pertanyaan-pertanyaan di dalam kertas yang telah ditekuk dan hiasi kertas asturo dengan gambar ular dan tangga. Selanjutnya membuat dadu dari kotak kecil bekas yang sudah disediakan lalu tempelkan kertas asturo dengan lem dan buat tanda dadu (titik kecil 1-6) dengan spidol.

Adapun cara mainnya: Setiap anak yang ingin main tinggal mengocok dadu. Angka berapa yang keluar dari dadu yang dikocok menunjukkan anak tersebut harus melangkah berapa langkah dari setiap kotak yang ditempati awal olehnya. Ketika berhenti melangkah di suatu kotak perhatikan, bukalah kotak yang sudah ditekuk, kalau ada pertanyaan dijawab. Kemudian aturan mainnya yaitu, ketika berhenti di gambar awal tangga maka anak dapat naik atau melangkah beberapa kotak lagi. Tetapi ketika bertemu dengan ular maka mundur atau turun ke bawah dalam langkahnya. Materi 
belajar dalam media belajar melalui permainan ular tangga ini disesuaikan dengan yang dipelajari dalam bimbingan belajar.

Melalui Permainan ini memungkinkan anak untuk memecahkan masalah-masalah yang nyata dan juga memberikan pengalaman-pengalaman nyata dan dapat diulangi sebanyak yang dikehendaki, kesalahan-kesalahan operasional dapat diperbaiki. Selain itu juga membantu siswa meningkatkan kemampuan komunikatifnya dan membantu siswa yang sulit belajar dengan metode tradisional.

Dalam pelaksanaan pemberian motivasi melalui cerita dan games, anak- anak menunjukkan respon yang positif dengan sikap berani maju ke depan, riang dan ceria dalam belajar, berani bertanya, berani mengungkapkan pendapat, serta berani menyampaikan pesan moral dari cerita yang disampaikan. Penerapan pemberian motivasi melalui cerita dan games diharapkan dapat meningkatkan minat belajar anak usia SD dan SMP. Terlihat dengan adanya pemberian motivasi belajar melalui cerita dan games, minat belajar anak meningkat dan anak-anak lebih semangat belajar,

meskipun ada beberapa anak yang tidak suka games tetapi anak tersebut menunjukkan hal positif dalam kegiatan pemberian motivasi melalui cerita inspiratif, anak tersebut berani bertanya ataupun mengungkapkan pendapat. Terlihat setelah kegiatan KKN-DR pun anak-anak masih suka belajar dengan kami dan beberapa pemudi desa Nagarajati.

\section{KESIMPULAN}

Penerapan pemberian motivasi melalui cerita dan games untuk meningkatkan minat belajar anak usia SD dan SMP di Desa Nagarajati cukup baik. Kegiatan pemberian motivasi anak-anak menunjukkan respon yang positif dengan sikap berani maju ke depan, semangat belajar, berani bertanya, berani mengungkapkan pendapat, serta berani menyampaikan pesan moral dari cerita yang disampaikan. Dengan adanya penerapan pemberian motivasi melalui cerita dan games pada saat KKN-DR diharapkan dapat meningkatkan minat belajar anak. Berdasarkan observasi, wawancara, dan dokumentasi, pemberian motivasi melalui cerita dan games menunjukkan respon positif bahwa dengan kegiatan tersebut belajar jadi lebih asyik dan menarik sehingga anak-anak memiliki motivasi yang meningkat dari sebelumnya, adanya motivasi belajar yang kuat dalam diri peserta didik menyebabkan minat belajar yang tinggi.

Adapun saran untuk perbaikan kedepan adalah; (1) Bagi orang tua anak-anak untuk selalu memberikan motivasi kepada anak-anak agar terus tertanam dalam diri anak-anak semangat belajar. (2). Bagi masyarakat untuk selalu mendukung program-program yang berkaitan dengan pendidikan agar memotivasi anak untuk belajar sehingga minat belajar menjadi tinggi. 


\section{UCAPAN TERIMA KASIH}

Ucapan terima kasih penulis sampaikan yang sebesar-besarnya kepada:

1. Bapak Sahdi, selaku Kepala Desa Nagarajati, Kecamatan Panawangan, Kabupaten Ciamis

2. Jajaran perangkat desa, seluruh warga desa dan anak-anak SD serta SMP desa Nagarajati Kecamatan Panawangan, Kabupaten Ciamis yang telah ikut berpartisipasi dalam berjalannya program pengabdian ini.

\section{DAFTAR PUSTAKA}

Abdul Aziz Abdul Majid. 2002. Mendidik Dengan Cerita. Bandung: Remaja Rosdakarya Bakhri, Syaeful., Aziz, Abdul., Sarinah, Ririn. (2020). Pengetahuan dan Motivasi Untuk Menumbuhkan Minat Berinvestasi Pada Mahasiswa. Value: Jurnal Manajemen dan Akuntansi, 15(2), 60-73.

Eliska, Nining. 2018. Pengaruh Pemberian Games Pembuka Dan Penutup Pembelajaran Terhadap Motivasi Belajar Pada Mata Pelajaran Pendidikan Kewarganegaraan Murid Kelas V SDN 05 Tokkene Kecamatan Tanete Riaja Kabupaten Barru. PGSD. Fakultas Keguruan dan Ilmu Pendidikan. Universitas Muhammadiyah Makassar.

Majid, Abdul. 2001. Perencanaan Pembelajaran dan Mengembangkan Standar Kompetesi Guru. Bandung: PT Remaja Rosdakarya.

Mulatsih, Yustina Laurentius Sri. dkk. 2018. Peningkatan Kemampuan Menceritakan Kembali Isi Cerita Melalui Alat Peraga Gambar Seri di TK Negeri Pembina Kabupaten Sragen. Jurnal Pendidikan Usia Dini, 12(1).

Niak, Raisatun. 2014. Seabrek Game Asyik Edukatif untuk Mengajar PAUD/TK. Yogyakarta: Diva Press.

Nur'aeni, Farida. 2010. Membentuk Karakter Anak Dengan Dongeng. Surakarta: Indiparent.

Rahmat, Pupu Saeful. 2009. Penelitian Kualitatif. 2009. QUILIBRIUM, 5(9).

Sardiman, A.M. 2000. Interaksi dan Motivasi Belajar Mengajar. Jakarta: Grafindo Persada.

Setianingsih, Ayu. 2018. Game Online Dan Efek Problematikanya Terhadap Motivasi Belajar Siswa Pada Mata Pelajaran Pendidikan Agama Islam Di SMK Negeri 7 Bandar Lampung. Bimbingan dan Konseling Islam. Fakultas Dakwah dan Ilmu Komunikasi. Universitas Islam Negeri Raden Intan Lampung.

Utami, Septi Wahyu. 2019. Penerapan Pendidikan Karakter Melalui Kegiatan Kedisiplinan Siswa. Jurnal Pendidikan, 04(1). 
Zarkasi, F., \& Lutfianto, M. 2017. Pengaruh Permainan Matematika Terhadap Minat Belajar Siswa pada Mata Pelajaran Matematika. Pendidikan Matematika. Fakultas Ilmu Pendidikan. STKIP Al Hikmah Surabaya. 